$\begin{aligned} & \text { Sunshine deal } \\ & \text { Critics question } \\ & \text { Scripps Florida } \\ & \text { agreement } \\ & 04\end{aligned}$
05

\title{
Satellite loss throws Japan's space programme into disarray
}

\section{David Cyranoski, Tokyo}

Japan's space agency is facing tough questions this week after the unexplained loss of Midori-II, one of the nation's most ambitious scientific satellites to date.

Shuichiro Yamanouchi, president of the newly revamped Japan Aerospace Exploration Agency (JAXA), declared the Earth observation probe lost for good on 31 October, a week after it stopped sending signals home. "It's regrettable," Yamanouchi said of the loss of the ten-month-old mission. "At this point there's little more to say.'

But the failure of the $¥ 70$-billion (US\$630-million) project, which was carrying instruments for Japan's space partners Europe and the United States, is a heavy blow for the space agency, which was reconstituted only last month in a bid to boost the national space programme.

This is the second such loss in six years. In June 1997, Midori, a Japanese Earth observation satellite carrying French and US instruments, was lost after ten months of operation. And following a costly, decadelong struggle to establish a reliable rocketlaunching capacity, JAXA can scarcely afford this latest setback.

Midori-II was carrying five instruments for studying various oceanic, terrestrial and atmospheric features. They included an upgrade of a NASA instrument for measuring the oceans' interaction with climate that was lost with Midori. And the CNES, France's national space agency, had sent an identical version of its POLDER sensor to that on the previous mission. The sensor measures solar radiation from aerosols, clouds, the oceans and land surfaces.

Midori-II had already sent back important data for climate studies, its backers say. These included data on soil moisture and sea surface temperature obtained by JAXA's Advanced Microwave Scanning Radiometer from measurements of microwave emissions from Earth's surface and atmosphere.

But on 25 October, Midori-II began to miss data-transmission appointments. The satellite has not responded to signals since. It was later discovered that power generation from its solar battery paddle had fallen sharply

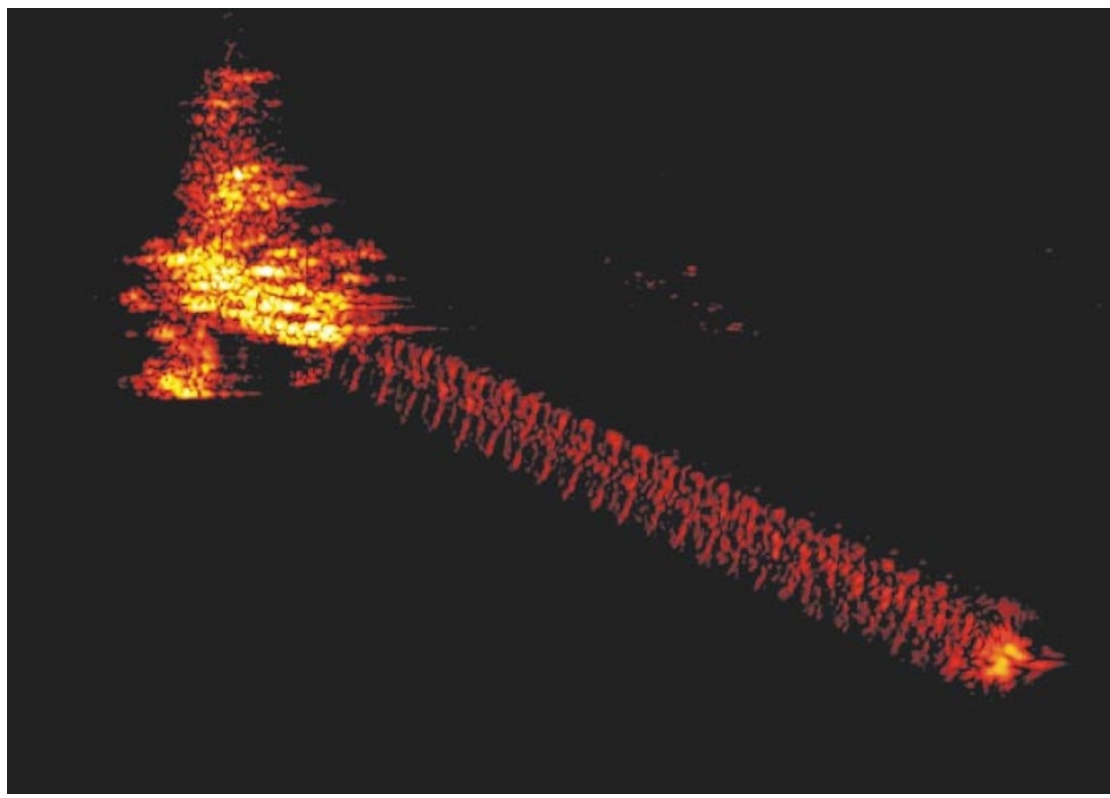

Radar images of troubled satellite Midori-II show that the solar panels powering the craft remain intact.

six hours earlier, from $6 \mathrm{~kW}$ to $1 \mathrm{~kW}$. JAXA is looking into the cause of the power loss.

The satellite was last observed in radar images taken by the Research Institute for High Frequency Physics and Radar Techniques in Wachtberg, Germany. They showed that the solar panels that powered the craft were still intact. Its predecessor's loss was directly attributed to damage to the solar panels.

JAXA is now under pressure to explain Midori-II's power problems. Initial reports blamed a solar flare - a sudden burst of energy from the Sun's surface - that sent a stream of charged particles into the atmosphere over Peru at the time Midori-II was passing. The timing coincided with the abrupt drop in power. But JAXA officials say they are not definitely blaming the flare.

"The solar flare is one consideration, but at this point we cannot say whether or not it had any relation," JAXA's associate executive director Tsuguhiko Katagi said at the 31 October press conference. JAXA has 100 researchers looking into the power failure. The investigation, led by Yamanouchi, will report to the education ministry's Space Activities Commission. But JAXA officials say that the inquiry could, as in the case of Midori, take up to six months.

Yamanouchi deflected questions about how JAXA might salvage its reputation, or how the gap left in Japanese Earth and climate studies would now be filled. "This research is a matter of international collaboration and will need to be discussed," he said.

"It was a real shocker for me," says Timothy Liu, the SeaWinds project director at NASA's Jet Propulsion Laboratory in Pasadena, California. The SeaWinds scatterometer for measuring ocean wind speeds was also lost on Midori-II. After the loss of its first device in 1997, Liu's lab used spare parts for fast assembly of a replacement. Liu says it has been "very disappointing to lose both satellites" and adds that they have no money for a replacement. $\mathrm{He}$ does not rule out any future collaboration with Japan's space programme. "But we hope that by that time Japan has improved its assessment and response measures," he adds.

http://sharaku.eorc.jaxa.jp/ADEOS2/sensor/ sensor.html 